\title{
Primary School Teachers' Knowledge on Tooth Avulsion
}

\section{Znanje učitelja osnovnih škola o avulziji zuba}

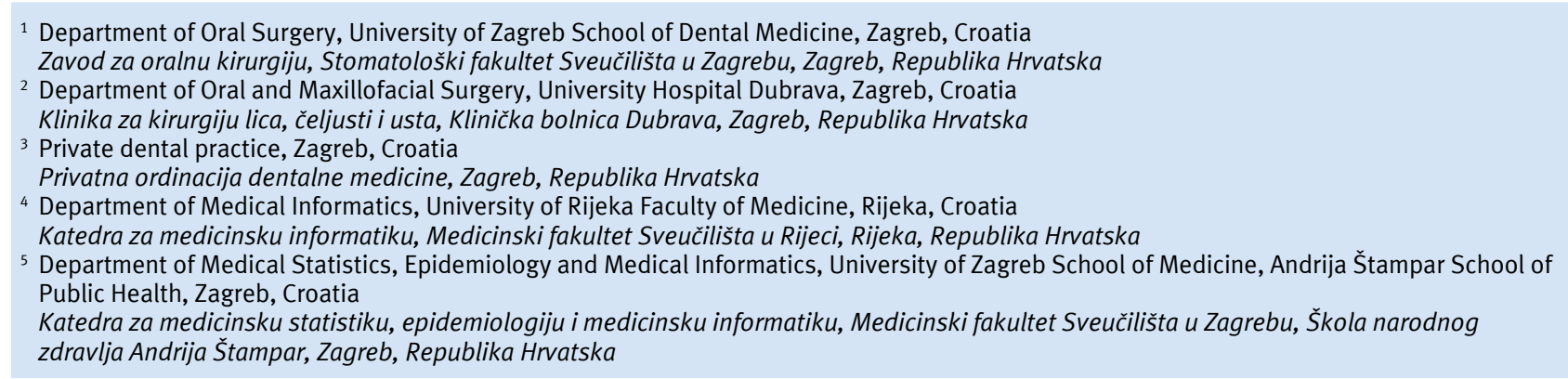

Abstract

Objective: Permanent teeth trauma is most frequent in children aged 7-9 years, and the primary school teachers (PSTs) are often the first to notice it. The aim of this study was to evaluate the competence in tooth avulsion clinical issues and knowledge on dental trauma of PSTs, as they can occasionally take on the role of school nurses. Material and Methods: Questionnaires were handed to 312 PSTs from 24 randomly selected primary schools in Zagreb, Croatia. An algorithm was designed for PST competence assessment. Results: Response rate amounted to $81.37 \%(\mathrm{~N}=255)$. Only $3.14 \%$ $(\mathrm{N}=8)$ of the PSTs would replant the permanent tooth properly and only $43.92 \%$ of them $(\mathrm{N}=112)$ would immediately take the child to a doctor of dental medicine. Dry tissue, as a transport medium for an avulsed tooth, was chosen by $50.20 \%(\mathrm{~N}=128)$ of the respondents. Altogether, $4.71 \%(\mathrm{~N}=12)$ of PSTs were graded as competent in case of child's tooth avulsion. Conclusion: These results provided significant implications for school health, showed the educators' serious lack of knowledge in cases of dental trauma and stressed a need for continuous education of PSTs on the topic.
Received: November 30, 2020

Accepted: February 17, 2021

Address for correspondence Professor Darko Macan, PhD University of Zagreb School of Dental Medicine Department of Oral and Maxillofacial Surgery

University Hospital Dubrava

Av. Gojka Suska 6, 10000 Zagreb, Croatia

Phone: 00385914664075

Fax: 0038514684441

darkom@kbd.hr

MeSH terms: Tooth Avulsion; School Teachers; Health Knowledge Attitudes Practice; Dental Health Education Author keywords: Educational Measurement; Attitude; Health education, Dental; Knowledge; Questionnaires; Tooth avulsion

\section{Introduction}

Tooth injury is the most common trauma of the orofacial region(1). Dental trauma can vary from a simple fracture to the avulsion of the tooth (2). Studies have shown different incidence rates of dental trauma, from 10.2 to $69.2 \%$ (3, 4 ), out of which tooth avulsion makes an average of $13.6 \%$ $(3,5)$.

Tooth avulsion is a complete tooth displacement from the tooth socket and is most frequent with children aged between 7 and 9 years (1). It leads to drying, ischemia and bacterial contamination of the tooth pulp and the periodontal ligament which supports the tooth in the alveolus (tooth socket). Even after short extra-alveolar time (outside the tooth

\section{Uvod}

Trauma zuba najčešća je u orofacijalnoj regiji (1) i može varirati od jednostavne frakture do avulzije (2). Istraživanja su pokazala incidenciju dentalne traume od 10,2 do 69,2 $\%(3,4)$, među kojima se avulzija zuba prosječno pojavljuje u 13,6 \% slučajeva $(3,5)$. Avulzija zuba potpuna je dislokacija zuba iz alveole te je najčešća među djecom u dobi između 7 i 9 godina (1). Ako se dogodi, počinje isušivanje, ishemija i bakterijska kontaminacija pulpe zuba i parodontnoga ligamenta. Čak i nakon kratkoga ekstraalveolarnog razdoblja nastaje trajno oštećenje parodontnoga ligamenta i stanica pulpe zuba. Zbog svega toga trajni zub valja replantirati u najkraćem mogućem roku. Ako je ekstraalveolarno vrijeme kraće 
socket),a permanent damage of the periodontal ligament and pulp cells appears. This is why a permanent tooth, if knocked out, should be replanted back to the alveolus as soon as possible. If the extra-alveolar time is shorter than an hour, complete or partial reparation of periodontal ligament is possible $(1,6)$. If this time is longer, the destruction of periodontal ligament cells takes place. Replantation in this period often results in progressive tooth root resorption $(1,2)$. Therefore, the time between the injury and the treatment is the most important factor for the therapy success $(1,8)$.

After avulsion, the tooth is contaminated and should be rinsed under running tap water $(1,7,8)$. Antiseptic solutions should not be used as they lead to destruction of the periodontal ligament cells. Mechanical cleaning of the tooth root removes the periodontal ligament cells and increases the possibility of ankylosis and resorption $(1,9)$. Tooth ankylosis is a condition in which the tooth root loses its normal attachment to the bone (periodontal ligament) and fuses directly to the alveolus.

Apart from the extra-alveolar time, the outcome also depends on the transport medium. Tap water, alcohol and dry wipes are the worst choices, as they do not preserve the vitality of the cells $(7,8)$. The best way to store and transport the avulsed tooth are specialized media (10-12).

Since trauma most frequently occurs in pre-schools and primary schools $(1,13)$, major role in the intervention can be carried out by educators and teachers, as they could easily be obliged to take on the role of school nurses. Therefore, their knowledge and prompt response can often determine the fate of the traumatized tooth.

Tooth rescue kits can preserve an avulsed tooth up to 24 hours and should be obligatory for every kindergarten and primary school $(14,15)$.

The aim of this study is to assess primary school teachers' (PSTs) knowledge, response and competence to cope with dental trauma. Primary school teachers have completed original competence assessment questionnaires.

\section{Material and Methods}

\section{Participants}

Questionnaires were personally handed to 312 PSTs from 24 primary schools in Zagreb, Croatia. Systemic sampling randomization technique was used to select primary schools.

Sample size analysis with power of $90 \%$ and the alpha level of 0.05 showed a minimum of 140 respondents for conducting this study $(16,17)$.

\section{Procedure}

Questionnaires were handed only to PSTs who wished to participate in research. All PSTs from one school filled the questionnaire at the same time. While filling the questionnaire, PSTs were monitored by the investigators, thus assuring the accuracy of the data provided.

The survey was conducted between July and September 2014 on weekdays.

With the purpose of raising awareness and educating the respondents, an information leaflet was provided after ex- od jednoga sata, moguća je potpuna ili djelomična reparacija parodontnoga ligamenta $(1,6)$. Ako je to razdoblje dulje, počinju umirati stanice parodontnoga ligamenta. Replantacija zuba u tom vremenu najčešće rezultira progresivnom resorpcijom korijena zuba $(1,2)$. Zato je vrijeme između traume i liječenja najvažniji čimbenik u ishodu liječenja $(1,8)$.

Nakon avulzije zub je kontaminiran i potrebno ga je isprati pitkom vodom $(1,7,8)$. Ne preporučuje se korištenje antiseptika jer oštećuju stanice parodontnoga ligamenta. Mehaničkim čišćenjem korijena zuba uklanjaju se stanice parodontnoga ligamenta te se u slučaju replantacije povećava mogućnost nastanka ankiloze ili resorpcije korijena $(1,9)$. Ankiloza zuba stanje je kada zub gubi normalnu vezu s kosti te se stapa sa zubnom alveolom.

Osim o ekstraalveolarnom grebenu, ishod također ovisi o transportnom mediju u kojemu se izbijeni zub prenosi u ordinaciju doktora dentalne medicine. Voda, alkohol i rupčić najlošiji su izbor jer ne čuvaju vitalitet stanica $(7,8)$. Najbolji način za prijenos izbijenoga zuba jest pohrana u posebnim medijima $(10-12)$. Kako je dentalna trauma najčešća kod predškolske djece te učenika u osnovnim školama $(1,13)$, u intervenciji mogu biti vrlo važni odgojitelji i učitelji jer nerijetko preuzimaju ulogu medicinske sestre. Zato njihovo znanje i brza reakcija mogu odrediti sudbinu traumatiziranoga zuba.

Kitovima za spašavanje zuba koji sadržavaju poseban medij za njegovu pohranu može se očuvati izbijeni zub do 24 sata te bi ih svaki vrtić i osnovna škola obvezno trebali imati $(14,15)$.

Cilj ovog istraživanja bio je upitnikom procijeniti znanje, spremnost i sposobnost učitelja osnovnih škola u slučaju traume zuba.

\section{Materijal i metode}

\section{Sudionici i postupak}

Anketni upitnik dobilo je osobno 312 učitelja iz 24 osnovne škole u Zagrebu.

U odabiru osnovnih škola korišstena je tehnika sistemske randomizacije. Analiza veličine uzorka, uz snagu $90 \%$ i alfarazinu od 0,05 , pokazala je da je za provođenje ovog istraživanja potrebno najmanje njih $140(16,17)$.

\section{Postupak}

Upitnik su dobili isključivo učitelji koji su izrazili želju za sudjelovanjem. Svi učitelji iz jedne škole istodobno su ispunjavali upitnik. Tijekom popunjavanja istraživači su nadzirali učitelje osiguravajući tako točnost dostavljenih podataka. Istraživanje je provedeno radnim danima između srpnja i rujna 2014. godine. Nakon ispitivanja, u svrhu podizanja svijesti i edukacije ispitanika, učitelji su dobili informativni letak u kojemu je opisan točan postupak u slučaju avulzije zuba prema smjernicama Međunarodne udruge za dentalnu trau- 
amining all of the primary school teachers involved in this study, containing the proper procedure in case of tooth avulsion, equivalent to the one released by the International Association of Dental Traumatology (IADT) (7).

\section{Questionnaire}

The questionnaire consisted of 27 questions and was divided in four parts. The first part was comprised of five questions concerning personal and professional data i.e. gender, age, educational level, years of employment and personal background.

The second part consisted of six questions that revealed PST's experience with dental trauma and assessed the knowledge on tooth avulsion and primary and secondary dentition.

The third part, i.e. questions 12-20 noted PST opinion and response in tooth avulsion situations.

The fourth part contained questions about tooth replantation, rinsing, storage and transport media of the avulsed tooth and PSTs' wish to learn more about the topic.

\section{Competence assessment}

The assessment of competence was evaluated by questions 15-26 of the survey and was rated individually. Within these questions, there was a possibility of more than one correct answer. The researchers determined a PST as "competent" and "incompetent" through a competence assessment algorithm. In order for a PST to be assessed competent, he/ she could either choose to adequately replant a permanent matologiju (engl. International Association of Dental Traumatology-IADT)) (7).

\section{Anketni upitnik}

Anketni upitnik sastojao se od 27 pitanja i bio je podijeljen u četiri dijela. Prvi dio sadržavao je pet pitanja o osobnim i profesionalnim karakteristikama, tj. o spolu, dobi, obrazovanju, godinama staža i podrijetlu. Drugi dio sastojao se od šest pitanja o iskustvu učitelja $s$ dentalnom traumom kako bi se procijenilo znanje o avulziji zuba te o mliječnoj i trajnoj denticiji.

Treći dio, tj. pitanja od 12. do 20., postavljena su zato da se doznaju stajališta i snalažljivost učitelja u slučaju avulzije zuba. Cetvrti dio bila su pitanja o replantaciji zuba, ispiranju, skladištenju i izboru transportnog medija za izbijeni zub.

\section{Procjena kompetencije}

Procjena kompetencije ocjenjivana je u anketnom upitniku od 15. do 26. pitanja i to za svakog ispitanika pojedinačno. U sklopu tih pitanja moglo se dati više točnih odgovora. Istraživači su procijenili učitelja kao kompetentnoga i nekompetentnoga na temelju algoritma za procjenu kompetencije. Da bi učitelj bio ocijenjen kompetentnim, morao je adekvatno replantirati trajni zub ili osigurati najbrži prijevoz djeteta
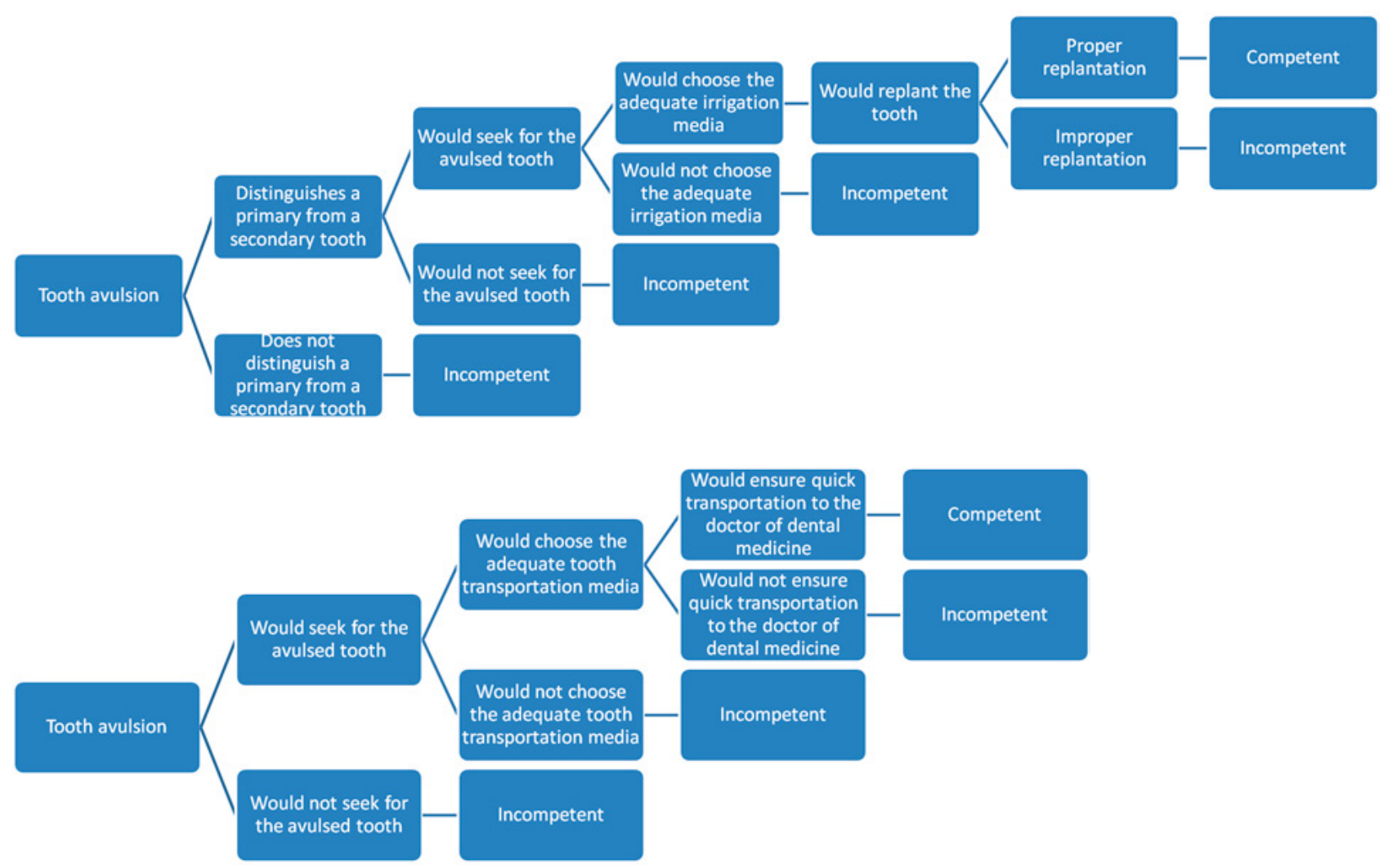

Figure 1 Competence assessment algorithm for tooth replantation

Slika 1. Algoritam za procjenu kompetentnosti za replantaciju trajnog zuba

Figure 2 Competence assessment algorithm for tooth transportation to a doctor of dental medicine

Slika 2. Algoritam za procjenu kompetentnosti za transport doktoru dentalne medicine 
tooth or secure the quickest transportation to the doctor of dental medicine. Both solutions were expressed as separate algorithms (Figures 1 and 2). Proper replantation implied choosing the adequate irrigation media, avoiding the mechanical cleaning of the permanent tooth root surface and its proper handling.

This survey was reviewed and approved by the Ethic Committee of the School of Dental Medicine, University of Zagreb, Croatia. The teachers who agreed to take part in the survey were assured of strict confidentiality and signed a written consent for taking part in the survey.

\section{Statistical analysis}

All submitted surveys were coded and analyzed. The results were processed in numerical order and expressed in percentages. The data were organized into files (Microsoft Excel, Microsoft Inc., USA) and processed by JMP7 module from the software package SAS (SAS Institute Inc., Cary, NC, USA). Fischer's test was applied to test the hypothesis. The Chisquared test, where applicable, was used to compare qualitative data. Statistically significant results were found only if $\mathrm{p}<0.05$.

\section{Results}

Out of 312 handled questionnaires, 57 (18.3\%) PSTs refused to take part in the survey; therefore the response rate was $81.73 \%$. Only completely filled questionnaires met the inclusion criteria. Sample description by age and sex is presented in Table 1. Significantly larger numbers of female respondents were included in this study ( $96.47 \%$ of all respondents).

Eighty-four (32.94\%), out of 255 primary school teachers, encountered dental trauma during their professional career. More than half $(\mathrm{N}=163 ; 63.92 \%)$ of PSTs did not know the age at which a child has all the permanent teeth and 108 (42.35\%) of them would not seek professional help after the avulsion of a primary tooth. Altogether, 25 (9.80\%) PSTs would not seek professional help after the avulsion of a permanent tooth. In case of a tooth avulsion, $43.92 \%(\mathrm{~N}=112)$ u ordinaciju doktora dentalne medicine. Oba rješenja izražena su kao zasebni algoritmi (slike 1. i 2.). Pravilna replantacija podrazumijevala je odabir odgovarajućeg medija za ispiranje, izbjegavanje mehaničkog čišćenja površine korijena trajnoga zuba i pravilno rukovanje zubom.

Ovo istraživanje pregledalo je i odobrilo Etičko povjerenstvo Stomatološkog fakulteta Sveučilišta u Zagrebu. Učiteljima koji su pristali sudjelovati u anketi osigurana je stroga povjerljivost podataka i svi su morali potpisali informirani pristanak.

\section{Statistička analiza}

Svaki anketni upitnik bio je kodiran i analiziran. Rezultati su obrađeni numeričkim redoslijedom i izraženi relativnim frekvencijama. Podatci su bili organizirani u datoteke (Microsoft Excel, Microsoft Inc., SAD) i obrađeni modulom JMP7 iz softverskoga paketa SAS (SAS Institute Inc., Cary, NC, SAD). Za provjeru hipoteze primijenjen je Fischerov test. Za usporedbu kvalitativnih podataka korišten je hi-kvadrat test gdje je to bilo primjenjivo. Statistički značajni rezultati pronađeni su samo ako je $\mathrm{p}<0,05$.

\section{Rezultati}

Upitnike je dobilo 312 učitelja, a njih 57 (18,3\%) odbilo je sudjelovati u istraživanju, pa je zato stopa odgovora bila $81,73 \%$. Samo su potpuno popunjeni upitnici zadovoljili kriterije za uključivanje u istraživanje. Opis uzorka prema dobi i spolu nalazi se u tablici 1 . $U$ istraživanje je bilo uključeno znatno više učiteljica $(96,47 \%$ svih ispitanika).

Od sveukupno 255 učitelja, njih 84 (32,94\%) susrelo se $s$ dentalnom traumom tijekom karijere. Više od polovine učitelja ( $\mathrm{N}=163 ; 63,92 \%)$ nije znalo u kojoj dobi dijete ima sve trajne zube, a njih $108(42,35 \%)$ ne bi tražilo stručnu pomoć nakon avulzije mliječnoga zuba. Ukupno 25 učitelja $(9,80 \%)$ ne bi tražilo stručnu pomoć nakon avulzije trajnoga zuba. U slučaju avulzije zuba, $43,92 \%$ učitelja $(\mathrm{N}=112)$ tražilo bi pomoć od doktora dentalne medicine, a 27,06 \%

\begin{tabular}{|c|c|c|c|c|c|c|}
\hline Age $\bullet$ Dob & $20-30$ & $31-40$ & $41-50$ & $>51$ & Total • Ukupno & $\begin{array}{c}\text { Statistics } \\
\text { Statistika }\end{array}$ \\
\hline Male • Muškarci & 1 & 2 & 4 & 2 & 9 & $\chi^{2}=0.45$ \\
\hline Female $\bullet$ Žene & 30 & 75 & 85 & 56 & 246 & $P=0.93$ \\
\hline Total • Ukupno & 31 & 77 & 89 & 58 & 255 & \\
\hline
\end{tabular}

\begin{tabular}{|c|c|c|}
\hline Professional help • Stručna pomoć & $\mathbf{N}$ & $\%$ \\
\hline Doctor of dental medicine $\bullet$ Doktor dentalne medicine & 112 & 43.92 \\
\hline Only the child's parents $\bullet$ Samo roditelje & 95 & 37.25 \\
\hline Wouldn't seek for professional help $\bullet$ Ne bih tražio/la stručnu pomoć & 25 & 9.80 \\
\hline Hospital $\bullet$ Bolnica & 10 & 3.92 \\
\hline Other $\bullet$ Ostalo & 8 & 2.92 \\
\hline General practice doctors $\bullet$ Doktor opće prakse & 5 & 1.96 \\
\hline
\end{tabular}


Table 3 Primary school teachers' selection of the irrigation solution for an avulsed permanent tooth

Tablica 3. Odabir irigacijskog sredstva učitelja za ispiranje avulziranog trajnog zuba

\begin{tabular}{l|c|c}
\multicolumn{1}{c|}{ Irrigation solution } & N & $\%$ \\
Wouldn't irrigate $\bullet$ Ne bih ispirao/la & 167 & 65.49 \\
\hline $70 \%$ alcohol $\bullet 70 \%$ alkohol & 49 & 19.21 \\
\hline Milk $\bullet$ Mlijeko & 16 & 6.27 \\
\hline Mouthwash $\bullet$ Vodica za usta & 21 & 8.24 \\
\hline Dry tissue $\cdot$ Suha maramica & 0 & 0 \\
\hline Saliva $\bullet$ Slina & 0 & 0 \\
\hline Saline solution $\bullet$ Fiziološka otopina & 0 & 0 \\
\hline Tap water $\bullet$ Voda iz slavine & 0 & 0 \\
\hline Other $\bullet$ Ostalo & 2 & 0.78 \\
\hline
\end{tabular}

\begin{tabular}{|c|c|c|}
\hline Transport medium $\bullet$ Transportni medij & $\mathbf{N}$ & $\%$ \\
\hline Dry tissue $\bullet$ Suha maramica & 128 & 50.20 \\
\hline Milk • Mlijeko & 32 & 12.54 \\
\hline A plastic bag $\bullet$ Plastična vrećica & 26 & 10.20 \\
\hline Place the avulsed tooth in the hand of a child $\bullet$ Stavio bih avulzirani zub u ruku djeteta & 18 & 7.06 \\
\hline $70 \%$ alcohol $\bullet 70 \%$ alkohol & 18 & 7.06 \\
\hline Kitchen foil $\bullet$ Kuhinjska folija & 10 & 1.96 \\
\hline Saliva $\bullet$ Slina & 4 & 1.57 \\
\hline Mouthwash $\bullet$ Vodica za usta & 4 & 1.57 \\
\hline Saline solution $\bullet$ Fiziološka otopina & 0 & 0 \\
\hline Tap water $\bullet$ Voda iz slavine & 0 & 0 \\
\hline Other $\bullet$ Ostalo & 0 & 0 \\
\hline Would try to reimplant the tooth $\bullet$ Pokušao/la bih replantirati zub & 15 & 5.88 \\
\hline
\end{tabular}

of PSTs would seek help from a doctor of dental medicine, while $27.06 \%$ of PSTs $(\mathrm{N}=69)$ would not seek for the permanent avulsed tooth. Primary school teachers' selection of professional help in case of permanent tooth avulsion is presented in Table 2.

The selection of an irrigation solution and transport medium to the professional care giver are presented in Tables 3 and 4. Replantation of a primary tooth as a treatment option would be considered by 11PSTs (4.31\%), while replantation of the permanent avulsed tooth by 15 PSTs (5.88 \%). From those who considered permanent tooth replantation, only 8 teachers $(3.14 \%)$ would do it properly.

The competence algorithm showed that 12 (4.71\%) PSTs were competent, while 36 (14.12\%) PSTs considered themselves personally competent in cases of tooth avulsion.

There was no connection between age (Fisher's test, $\mathrm{p}=0.5040$ ), educational level (Fischer's test, $\mathrm{p}=0.5460$ ), origin (Fischer's test, $\mathrm{p}=0.3986$ ) or duration of employment (Fischer's test, $\mathrm{p}=0.5860$ ) and level of competence.

Respondents showed interest in the topic and $98.04 \%$ $(\mathrm{N}=250)$ of them expressed a wish to learn more about dental trauma.

\section{Discussion}

Because of an impressive clinical picture, often followed by distress and bleeding in the area of face and mouth, seeking for the avulsed tooth does not present a priority for peo-
PST-a $(N=69)$ ne bi tražilo izbijeni trajni zub. Izbor stručne pomoći koju bi tražili učitelji osnovnih škola u slučaju avulzije trajnoga zuba prikazan je u tablici 2.

Odabir učitelja, kad je riječ o otopini za ispiranje i transportnom mediju u slučaju avulzije zuba, nalazi se u tablicama 3 i 4. Replantaciju mliječnoga zuba kao mogućnost liječenja uzelo bi u obzir 11 učitelja (4,31\%), a replantaciju trajnoga avulziranoga zuba njih 15 (5,88 \%). Od svih onih ispitanika koji bi replantirali trajni zub, samo 8 učitelja $(3,14$ $\%)$ učinilo bi to pravilno.

Algoritmom za procjenu kompetencije 12 učitelja (4,71 $\%)$ ocijenjeno je kompetentnima, a sveukupno se njih 36 $(14,12 \%)$ smatra osobno kompetentnima u slučaju avulzije zuba.

Nije bilo povezanosti između dobi (Fisherov test, $\mathrm{p}=$ 0,5040 ), stupnja obrazovanja (Fischer-ov test, $\mathrm{p}=0,5460$ ), podrijetla (Fischerov test, $\mathrm{p}=0,3986$ ) ili godina staža (Fischerov test, $\mathrm{p}=0,5860)$ i kompetencije učitelja.

Ispitanici su pokazali zanimanje za temu i $98,04 \%$ učitelja $(\mathrm{N}=250)$ izrazilo je želju da doznaju više o dentalnoj traumi.

\section{Rasprava}

Zbog impresivne kliničke slike, često praćene izrazitom anksioznošću i krvarenjem u području lica i usta, traženje avulziranoga zuba nije prioritet u kontaktu s traumatizira- 
ple in contact with a traumatized child. Firstly, it is essential that life-threatening injuries are excluded. However, afterwards, it is necessary that the permanent tooth is found and properly handled. The fact that $27.06 \%$ of PST $(\mathrm{N}=69)$ would not seek the permanent tooth when knocked out demonstrates incompetence "a priori". According to the IADT,an avulsed tooth has the best prognosis if rinsed under running tap water for 10s maximum, without mechanical cleaning and if replanted within 30-60 minutes in the dental alveolus (7). Unfortunately, only $5.88 \%$ of PSTs $(\mathrm{N}=15)$ would replant a permanent tooth, out of which only eight of them would do it properly. This piece of information does not differ from foreign research $(18,19)$.

Primary avulsed teeth should not be replanted, nevertheless $4.31 \%(\mathrm{~N}=11)$ of our respondents would do so. This procedure can damage the bud of the permanent tooth. Even though a systemic review on primary tooth replantation showed outcomes without negative consequences in 15 out of 41 cases, there remains no evidence on its validity (20).

If it's decided not to replant the avulsed permanent tooth, a selection of transport media and quick transportation to the doctor of dental medicine is crucial.

Most of PSTs (50.20\%; N=128) in our study would use a dry tissue as a transport medium, which, as well as tap water, distilled water, ice, alcohol and mouthwash leads to dehydration of cells and causes their degradation $(6,10,19)$. Similar results are noted in other papers (21-23). Milk has the osmolality and $\mathrm{pH}$ value similar to the cells of the periodontal ligament, has valuable nutritional substances and allows the maintenance of cell viability during six hours $(6,13)$. Milk as a transport medium was selected by $12.54 \%(\mathrm{~N}=32)$ of our respondents. A solution similar to saline solution is easily prepared by dissolving a teaspoon of salt in two deciliters of water. Milk has obtained acceptance as storage medium. Likewise, a readily accessible saline solution can be used as a transport medium. None of PSTs selected it as a transport medium. Every household with children should own a specialized media kit, not to mention the necessity of it in kindergartens and schools.

Since every avulsed tooth has a good prognosis if replanted within an hour, it is worrisome that $37.25 \%(\mathrm{~N}=95)$ of PSTs would only inform the parents, thus leaving the child's future care to them and wasting precious time, that only $43.92 \%(\mathrm{~N}=112)$ of them would ensure immediate transportation to the doctor of dental medicine, that $80.00 \%$ $(\mathrm{N}=204)$ of them would not choose the right medium for transporting the avulsed tooth, that most of them would not consider tooth replantation, and that $63.92 \%(\mathrm{~N}=163)$ of them do not even know at what age a child has all of his/her permanent teeth (not including wisdom teeth).

Unfortunately, school policy on dental trauma and healthcare is often not defined at the national level, but varies from school to school. Consequently, school teachers sometimes must completely take on the role of school nurses.

The results of this study have not brought new insights on the level of PST knowledge since the lack of it is reported in other similar studies on the topic (24-28). However, the novel algorithm proved rigorous, simple and exact. Compe- nim djetetom. Ponajprije je bitno isključiti ozljede opasne za život. No nakon toga potrebno je pronaći izbijeni trajni zub i pravilno rukovati njime. Činjenica da $27,06 \%$ učitelja (N = 69) ne bi tražilo avulzirani trajni zub a priori pokazuje nekompetentnost. Prema IADT-u, avulzirani zub ima najbolju prognozu ako se desetak sekunda ispire tekućom vodom iz slavine, bez mehaničkog čišćenja korijena te ako se ponovno replantira u zubnu alveolu u roku od 30 do 60 minuta (7). Nažalost, samo 5,88 \% učitelja $(\mathrm{N}=15)$ odlučilo bi se replantirati trajni zub, od čega bi samo njih osam to učinilo pravilno. Ovi se podatci ne razlikuju od stranih istraživanja $(18,19)$.

Mliječni avulzirani, izbijeni zubi ne bi se smjeli replantirati, no $4,31 \%$ učitelja $(\mathrm{N}=11)$ odlučio bi se na taj postupak koji može rezultirati oštećenjem zametka trajnoga zuba. Iako je u jednom sustavnom preglednom istraživanju o replantaciji mliječnih zuba istaknuto da su postignuti rezultati bez negativnih posljedica u 15 od 41 slučaja, i dalje nema dokaza o opravdanosti replantacije mliječnih zuba (20).

Ako se odustane od replantacije trajnoga zuba, presudan je odabir transportnog medija i što raniji odlazak doktoru dentalne medicine.

Većina učitelja $(50,20 \% ; \mathrm{N}=128)$ u ovom istraživanju koristila bi se suhim rupčićem kao transportnim medijem koji, kao i voda iz slavine, destilirana voda, led, alkohol i vodica za usta, dehidriraju stanice paradontnoga ligamenta i uzrokuju njihovo propadanje $(6,10,19)$. Slični rezultati zabilježeni su i u drugim istraživanjima $(21-23)$. Mlijeko ima osmolalnost i $\mathrm{pH}$ vrijednost sličnu stanicama parodontnoga ligamenta, sadržava vrijedne hranjive tvari i omogućuje preživljavanje stanica šest sati $(6,13)$. Trajno mlijeko kao transportni medij odabralo je $12,54 \%$ učitelja $(\mathrm{N}=32)$. Otopina slična fiziološkoj lako se priprema otapanjem žličice soli u pola čaše vode. Kao i trajno mlijeko, to je rješenje pristupačan transportni medij. Nijedan učitelj ne bi ga odabrao kao transportni medij. Svako kućanstvo s djecom trebalo bi imati poseban medij za transport izbijenoga zuba, a to se posebice odnosi na vrtiće i osnovne škole.

Kako je poznato da izbijeni zub ima najbolju prognozu ako se replatnira u roku od jednoga sata, zabrinjavaju rezultati da bi $37,25 \%$ učitelja $(\mathrm{N}=95)$ obavijestilo roditelje, prepuštajući im buduću skrb o djetetu i gubeći dragocjeno vrijeme, da bi samo njih 43,92\% ( $\mathrm{N}=112)$ osiguralo neposredan prijevoz u ordinaciju doktora dentalne medicine, da 80,00 \% $(\mathrm{N}=204)$ ne bi odabralo ispravan medij za transport izbijenoga zuba, da većina ne bi razmotrila replantaciju trajnoga zuba te da $63,92 \%$ učitelja $(\mathrm{N}=163)$ i ne zna u kojoj dobi dijete ima sve trajne zube (ne uključujući umnjake).

Nažalost, zdravstvena zaštita i zbrinjavanje dentalne traume nije definirano na nacionalnoj razini, nego se razlikuje od škole do škole, što rezultira time da katkad učitelji u školama moraju potpuno preuzeti ulogu školskih medicinskih sestara.

Rezultati ovog istraživanja nisu dali nove spoznaje kad je riječ o nedostatku znanja učitelja, jer se o tomu izvještavalo i u drugim sličnim studijama $(24-28)$. No kreirani algoritam pokazao se rigoroznim, jednostavnim i točnim. Kompetencija je procijenjena u anketnom upitniku u pitanjima od 15 . do 26., u kojima su ispitanici mogli biti ocijenjeni kompe- 
tence was assessed by questions 15-26 of the questionnaire in which the respondents were able to be assessed competent through two routes. As depicted in Figure 1, PSTs were able to pick a route where he/she was the child's therapist i.e. the route which included tooth replantation. The second route demanded that the avulsed tooth was properly handled and brought to the doctor of dental medicine as soon as possible (see Figure 2). Questionnaires with clinical cases can be found in the literature, however, to our knowledge, an algorithm as this one, has not yet been used for competence assessment in tooth avulsion issues. A similar algorithm could easily be applicable to other dental trauma cases.

As $32.94 \%(\mathrm{~N}=84)$ of PSTs had previously been in contact with dental trauma, it is needless to justify the need for their obligatory continuous education.

It is satisfying that $98.04 \%(\mathrm{~N}=250)$ of PSTs expressed a wish to find out more about the topic. Since only $14.12 \%$ $(\mathrm{N}=36)$ of teachers found themselves competent in tooth avulsion cases, their awareness of the lack of knowledge is clear. We expected a connection between the level of education, years of employment, background, experience and the assessed competence. However, we found no statistically significant difference.

A questionnaire, presented as a tool for knowledge and competence assessment, has its already familiar limitations as an indirect measurement tool $(29,30)$, since there are difficulties concerning the reproduction of real-time clinical situations, ensuring the truthfulness of the answers and respondents' recall or the response rate bias. Even though every researcher tends to provide the most accurate data, observer bias cannot be excluded, due to the respondents' questions during the examination. The answers given to them could not have been credible, but surely any information given was influential.

In order to educate PSTs about tooth avulsion, they were handed an information leaflet that simply describes the methods of managing the avulsed tooth.

A similar study, involving school nurses, would complement the evaluation of dental trauma management in primary schools.

\section{Conclusions}

Our results provide significant implications for school health and show the current lack of knowledge on dental trauma among primary school educators. Dental trauma in primary school is not uncommon. Teachers are the first to notice dental trauma, hence they will occasionally have to take on the role of school nurses.

The competence algorithm presents a simple, rigorous and innovative technique to assess knowledge on tooth avulsion and its design could easily be translated for competence assessment in other dental trauma cases and serve for educational purposes. These results are of utmost importance not only for PSTs, but also for doctors of dental medicine since they should instruct educators.

The fact that $95.29 \%$ of PSTs were assessed as incompetent for treating an avulsed tooth indicates the need for orga- tentnima na dva načina. Kao što je prikazano na slici 1. učitelji su mogli odabrati liječenje, tj. replantaciju trajnoga zuba. Alternativno su mogli odabrati hitan transport djeteta i zuba u ordinaciju doktora dentalne medicine, što je zahtijevalo pravilno rukovanje izbijenim zubom (slika 2.). Upitnike slične ovome može se pronaći u dostupnoj literaturi, međutim, prema našim saznanjima, algoritam za procjenu kompetencije još nije korišten za procjenu sposobnosti u slučaju avulzije zuba. Sličan algoritam mogao bi se lako primijeniti i na druge vrste dentalnih trauma.

Kako je 32,94 \% učitelja $(\mathrm{N}=84)$ uključenih u ovo istraživanje prije bilo u kontaktu s dentalnom traumom, nepotrebno je opravdavati potrebu za kontinuiranim obrazovanjem.

Pozitivno je što je 98,04\% učitelja $(\mathrm{N}=250)$ izrazilo želju da dozna više o toj temi. Kako se samo njih 14,12 \% (N = 36) proglasilo kompetentnima u slučajevima avulzije zuba, njihova svijest o nedostatku znanja je evidentna. Očekivali smo vezu između razine obrazovanja, godina staža, pozadine, iskustva i procijenjene kompetencije, no nismo pronašli statistički značajnu razliku.

Upitnik kao alat za procjenu znanja i kompetencija ima svoja već poznata ograničenja kao indirektni mjerni instrument $(29,30)$, a to su poteškoća u reprodukciji kliničkih situacija u stvarnom vremenu, osiguranje istinitosti odgovora ili otklon zbog prisjećanja (engl. recall bias). Iako svaki istraživač nastoji dobiti najtočnije podatke, pristranost promatrača ne može se isključiti zbog pitanja ispitanika tijekom provedbe istraživanja. Odgovori koji su im dani nikada nisu bili konkretni, ali mogli su imati utjecaj.

Kako bi se učitelji educirali o avulziji zuba, dani su im informativni letci u kojima su jednostavno opisane metode zbrinjavanja izbijenoga zuba.

Istraživanje slično ovome, ali usmjereno na školske medicinske sestre, dalo bi više informacija o spremnosti školskog sustava u zbrinjavanju dentalne traume kod djece.

\section{Zaključak}

Rezultati istraživanja pokazali su trenutačni nedostatak znanja učitelja osnovnih škola u zbrinjavanju avulzije zuba. Dentalna trauma u osnovnoj školi nije rijetkost te su učitelji prvi koji će je primijetiti te će katkad morati preuzeti i ulogu školskih medicinskih sestara.

Procjena kompetencije s pomoću predstavljenih algoritama je jednostavna, rigorozna i inovativna tehnika za procjenu znanja o avulziji zuba, a njezin dizajn jednostavno se može iskoristiti i za procjenu kompetencije u drugim slučajevima dentalne traume te može služiti u obrazovne svrhe. Ovi rezultati vrlo su važni ne samo za učitelje, nego i za doktore dentalne medicine kao potencijalne edukatore.

Rezultat da je 95,29 \% učitelja ocijenjeno nekompetentnima za zbrinjavanje avulziranog zuba upućuje na to da je potrebno stalno organizirati tečajeve o dentalnoj traumi. To 
nizing continuous obligatory courses on dental trauma. This can only be performed by studies like this one,aiming school teachers and school nurses through undergraduate and postgraduate curricula.

\section{Acknowledgments and conflict of interest}

The questionnaire and the information leaflet are available on request. The authors declare no conflict of interest.

Author's contribution: I.S., D.M. - research, data collection, formal analysis, interpretation, visualization, writing - original draft, approval of the final version of the article for publication; K.B., J.K. - concept and design, formal analysis, statistical analysis, interpretation, writing - critical review and editing, approval of the final version of the article for publication; A.M., P.D. - concept and design, supervision, interpretation, writing - critical review and editing, approval of the final version of the article for publication; J.B. - interpretation, formal analysis, critical review and editing, approval of the final version of the article for publication; D.M. - supervision, resources, concept and design, writing - critical review and editing, approval of the final version of the article for publication se može istaknuti samo studijama poput ove jer je usmjerena na kurikulum školskih učitelja i školskih medicinskih sestara.

\section{Sukob interesa i izjava}

Anketni upitnik i informativni letak dostupni su na zahtjev. Autori nisu bili u sukobu interesa.

Doprinos autora: S., D. M. T. - istraživanje, prikupljanje podataka, formalna analiza, interpretacija, vizualizacija, pisanje - originalni nacrt, odobravanje krajnje verzije članka za objavljivanje; K. B., J. K. - koncept i dizajn, formalna analiza, statistička analiza, interpretacija, pisanje - kritički pregled i uređivanje, odobravanje krajnje verzije članka za objavljivanje; A. M., P. Đ. - koncept i dizajn, supervizija, interpretacija, pisanje - kritički pregled i uređivanje, odobravanje krajnje verzije članka za objavljivanje; J. B. - interpretacija, formalna analiza, kritički pregled i uređivanje, odobravanje krajnje verzije članka za objavljivanje; D. M. - koncept i dizajn, supervizija, resursi, pisanje - kritički pregled i uređivanje, odobravanje krajnje verzije članka za objavljivanje

\section{Sažetak}

Cilj: Trauma trajne denticije najčešća je kod djece u dobi od 7 do 9 godina te su učitelji prvi koji je uočavaju. Avulzija je potpuno izbijanje zuba iz zubne alveole i najteži je oblik dentalne traume. S obzirom na to da učitelji osnovnih škola u takvim slučajevima najčešće preuzimaju ulogu školske medicinske sestre, svrha istraživanja bila je procijeniti njihovu sposobnost pri zbrinjavanju te znanje o avulziji zuba. Materijal i metode: Uručeno je 312 anketnih upitnika učiteljima iz 24 nasumično odabrane osnovne škole u Zagrebu. Izrađen je algoritam za procjenu sposobnosti zbrinjavanja djeteta. Rezultati: Odziv ispitanika iznosio je $81,37 \%(\mathrm{~N}=255)$. Samo 3,14 \% učitelja ispravno bi replantiralo trajni zub, a $49,92 \%$ odvelo bi učenika u najkraćem roku doktoru dentalne medicine. Polovina ispitanika $(50,2 \% ; N=128)$ spremila bi izbijeni zub u rupčić. Sveukupno je samo $4,71 \%$ ispitanika $(\mathrm{N}=12)$ ocijenjeno sposobnima za zbrinjavanje avulzije trajnoga zuba kod djece. Zaključak: Rezultati istraživanja otkrili su nedostatke u organizaciji školskog zdravstva, ozbiljan nedostatak znanja učitelja osnovnih škola te upozorili na nužnost kontinuirane izobrazbe učitelja kad je riječ o toj temi.
Zaprimljen: 30. studenoga 2020. Prihvaćen: 16. veljače 2021

Adresa za dopisivanje Prof.dr.sc. Darko Macan Sveučilište u Zagrebu Stomatološki fakultet Zavod za oralnu kirurgiju Klinika za kirurgiju lica, čeljusti i usta, K.B. Dubrava Av. Gojka Šuška 6, 10000 Zagreb Republika Hrvatska telefon: 00385914664075 fax: 0038514684441 darkom@kbd.hr

MeSH pojmovi: avulzija zuba; školski učitelij; zdravstvene spoznaje, stavovi i praksa; stomatološko obrazovanje Autorske ključne riječi: istraživanje obrazovanja, stajališta, zdravstveni odgoj, stomatološki, znanje, anketni upitnici, avulzija zuba

\section{References}

1. Andreasen JO, Andreasen FM, Bakland LK, Flores MT. Traumatic dental injuries. A Manual. 2nd ed. Oxford: Blackwell Munksgaard; 2003

2. Granger T, Alasdair G, Welbury R. Tooth replantation: a worthwhile exercise? Acta Stomatol Croat. 2011;45(2):75-85.

3. Emerich K, Czerwinska M, Ordyniec-Kwasnica I. Immediate selfreplantation of an avulsed permanent mandibular incisor - a case report. Dent Traumatol. 2010 Oct;26(5):443-6.

4. Sen-Yavuz B, Sadikoglu S, Sezer B, Toumba J, Kargul B. An Assessment of the Knowledge of Dentists on the Emergency Management of Avulsed Teeth. Acta Stomatol Croat. 2020;54(2):136 146.

5. Ivkošić I, Gavić L, Jerković D, Macan D, Vladislavić NZ, Galić N, et al. Knowledge and Attitudes about Dental Trauma Among the Students of the University of Split. Acta Stomatol Croat. 2020 Sep;54(3):302-313.

6. Fariniuk LF, Souza MH, Westphalen VP. Evaluation of care of dentoalveolar trauma. J Appl Oral Sci. Jul-Aug 2010;18(4):343-5.

7. Andersson L, Andreasen JO, Day P. International Association of Dental Traumatology guidelines for the management of traumatic dental injuries: 2. Avulsion of permanent teeth. Dent Traumatol. $2012 \mathrm{Apr} ; 28(2): 88-96$
8. Silva-Oliveira F, Goursand D, Ferreira RC, Paiva PCP, Paiva $\mathrm{HN}$, Ferreira EF, et al. Traumatic dental injuries in Brazilian children and oral health-related quality of life. Dent Traumatol. 2018 Feb;34(1):28-35.

9. Jain A, Kulkarni P, Kumar S, Jain M. Knowledge and Attitude of Parents towards Avulsed Permanent Tooth of their Children and its Emergency Management in Bhopal City. J Clin Diagn Res. 2017 May;11(5):ZC40-ZC44.

10. Adnan S, Lone MM, Khan FR, Hussain SM, Nagi SE. Which is the most recommended medium for the storage and transport of avulsed teeth? A systematic review. Dent Traumatol. 2018;34(2):59-70

11. Hasan MR, Takebe H, Shalehin N, Obara N, Saito T, Irie K. Effects of tooth storage media on periodontal ligament preservation. Dent Traumatol. 2017 Oct;33(5):383-392.

12. Khinda VIS, Kaur G, Brar GS, Kallar S, Khurana H. Clinical and Practical Implications of Storage Media used for Tooth Avulsion. Int I Clin Pediatr Dent. 2017;10(2):158-165.

13. Glendor U. Epidemiology of traumatic dental injuries-a 12 year review of the literature. Dent Traumatol. 2008 Dec;24(6):603-11.

14. Müller KE, Persic R, Pohl Y, Krastl G, Filippi A. Dental injuries in mountain biking--a survey in Switzerland, Austria, Germany and Italy. Dent Traumatol 2008;24(5):522-527. 
15. Bakarčić D, Hrvatin S, Maroević M, Ivančić Jokić N. First Aid Management in Emergency Care of Dental Injuries - Knowledge Among Teachers in Rijeka, Croatia. Acta Clin Croat 2017;56(1):110-116.

16. Barlett JE, Kotrlik JW, Higgins CC. Organizational Research: Determining Appropriate Sample Size in Survey Research. Information Technology, Learning, and Performance Journal. 2001;19(1):4350.

17. Jain A, Srilatha A, Doshi D, Nellutla A, Shoeb Alam K. Knowledge of emergency management of avulsed tooth among intern dental students: a questionnaire based study. Int I Adolesc Med Health. 2018 Aug 17;32(5).

18. Young C, Wong KY, Cheung LK. A Survey on Hong Kong Secondary School Students' Knowledge of Emergency Management of Dental Trauma. PLoS One. 2014;9(1):e84406.

19. Marcano-Caldera M, Mejía-Cardona JL, Parra Sanchez JH, Méndez de la Espriella C, Covo Morales E, Sierra Varón G, et al. Knowledge about emergency dental trauma management among school teachers in Colombia: A baseline study to develop an education strategy. Dent Traumatol. 2018 Jun;34(3):164-174.

20. Martins Júnior PA, Franco FA, de Barcelos RV. Replantation of avulsed primary teeth: a systematic review. Int J Paediatr Dent. 2014 Mar;24(2):77-83.

21. De Brier N, Dorien O, Borra V, Singletary EM, Zideman DA, De Buck E, et al. Storage of an avulsed tooth prior to replantation: A systematic review and meta-analysis. Dent Traumatol. 2020 Oct;36(5):453-476.

22. Shamarao S, Jain J, Ajagannanavar SL, Haridas R, Tikare S, Kalappa AA. Knowledge and attitude regarding management of tooth avulsion injuries among school teachers in rural India. J Int Soc Prev Community Dent. 2014; 4(Suppl 1):S44-S48.

23. Awad MA, Al Hammadi E, Malalla M, Maklai Z, Tariq A, Al-Ali B, et al. Assessment of Elementary School Teachers' Level of Knowledge and Attitude regarding Traumatic Dental Injuries in the United Arab Emirates. Int J Dent. 2017;2017:1025324.

24. Costa FW, de Oliveira EH, Bezzera MF. Dental trauma: knowledge and attitudes of community health workers. J Craniofac Surg. 2014;25(5):e490-495.

25. Al Gharsan M, Alarfaj I. Knowledge and practice of secondary school teachers about first aid. J Family Med Prim Care. 2019;8(5):1587-1593.

26. Daupare S, Narbutaite J. Primary school teachers' knowledge and attitude regarding traumatic dental injuries. J Indian Soc Pedod Prev Dent. 2020;38(3):216-221.

27. Gaffar B, Al Humaid J, Nazir MA, Alonazian F. Traumatic dental injuries in the Eastern Region of Saudi Arabia: Factors influencing teachers' management practices. Dent Traumatol. 2020. doi: 10.1111/edt.12598. Online ahead of print.

28. Tewari N, Goel S, Rahul M, Mathur VP, Ritwik P, Haldar P, et al. Global status of knowledge for prevention and emergency management of traumatic dental injuries among school teachers: A systematic review and meta-analysis. Dent Traumatol. 2020. doi: 10.1111/edt.12579. Online ahead of print.

29. Nur N. Turkish school teachers' knowledge and attitudes toward HIV/AIDS. Croat Med J. 2012 Jun;53(3):271-7.

30. Bazdaric K. Questionnaire structure - how much do editors need to know? Eur Sci Ed 2018;44(4):74-75. 